\title{
SOBRE ALGUNS ASPECTOS DA "TRADUTIBILIDADE" NOS CADERNOS DO CÁRCERE DE ANTONIO GRAMSCI E ALGUMAS DAS SUAS IMPLICAÇÕES
}

\author{
Rocco Lacorte*
}

\begin{abstract}
RESUMO
A questão sintetizada no título deste ensaio é de grande atualidade pelo fato de que o conceito expresso pela palavra "tradutibilidade" não implica apenas uma "tradução" entre linguagens em sentido estrito, mas, acima de tudo, um conceito revolucionário: aquele original e inovador de tradução entre "teoria" e "prática", filosofia e política, entendidas como "linguagens", embora em um sentido mais forte e amplo (por isso, coloquei - e o próprio Gramsci frequentemente coloca - estas palavras entre aspas). É minha intenção explicar as razões disso ao longo desta exposição. Por agora, pode-se antecipar que a tradutibilidade é a teoria da tradução entendida de uma forma que incorpora criticamente o velho no novo significado, mais amplo e forte, sendo, ao mesmo tempo, a condição (historicamente dada) para pensar de forma nova na possibilidade de construir política e historicamente uma "igualdade real" entre seres humanos, de modo a superar a atávica separação entre dominantes e subalternos, dirigentes e dirigidos, na medida em que pensa contemporaneamente na realidade do novo conceito de equivalência entre "teoria" e "prática" como elemento de hegemonia política - elemento que é ele mesmo político e, por isso, histórico. É isto que revela o coração da filosofia da práxis de Gramsci e permite entendê-la em profundidade. Desta "tradutibilidade" deriva uma série de critérios para interpretar a realidade. Portanto, a tradutibilidade expressa não só um jeito novo de ver o mundo e de construção do pensamento, mas implica também uma nova consciência. Isto é, a tradutibilidade é o conceito por meio do qual pensa-se na teoria como algo que muda (ou pode mudar) o mundo; e na prática como algo que mudando o mundo muda (ou pode mudar) também a teoria. Iluminada com o conceito de tradutibilidade, entende-se porque
\end{abstract}

* Rocco Lacorte é Ph.D. pela University of Chicago (Illinois, EUA). Membro do Núcleo de Estudos e Pesquisas em Filosofia, Política e Educação (NuFiPE) da UFF. 
a filosofia da práxis se põe como objetivo fundamental realizar uma grande reforma intelectual e moral das massas populares, por meio de um trabalho político-pedagógico-cultural, de modo a traduzir suas lutas e aspirações em uma nova e revolucionária filosofia e realidade.

Palavras-chave: Tradutibilidade. Linguagem. Filosofia. Política. Práxis.

\begin{abstract}
"Translatability" is a concept in Gramsci's work that has been largely unexplored and has only recently gained the attention of some scholars for its centrality to Gramsci's thought. So far, almost all the studies on Gramsci have essentially ignored the importance of this concept to the interpretation of his thought, work and biography on the whole. According to him, translatability is the theory of the concrete unification of practice and theory, that is, of how to radically change world; it theorizes both on the "practical power" and effectiveness of theory (i.e. on the impossibility of its transcendence) and on the "knowledge power" of practice. In other words, translatability means that practice and theory, as activities that belong to the same "world-view" or "express" the same culture, are not in contradiction one to the other (as, on the contrary, the main Western tradition of thought holds) and therefore are translatable. And indeed this is an innovative way of positing the conditions for thinking reality and praxis that we are going to explore in this brief essay.
\end{abstract}

Keywords: Translatability. Language. Philosophy. Politics. Praxis.

\title{
1 A tradutibilidade como fusão de paradigmas diferentes
}

Embora esteja presente também nos escritos juvenis, é sobretudo em sua obra Cadernos do Cárcere, a partir de 1930, que Antonio Gramsci desenvolve teórica e explicitamente a tradutibilidade. Como veremos, no $Q 8,208^{1}$, escrito no inverno-primavera de 1932 e dedicado explicitamente

1 De agora em diante, as referências aos Cadernos do Cárcere são a tradução pessoal da edição crítica GRAMSCI, A. Quaderni del carcere, V. Gerratana (Org.). Torino: Einaudi, 1975, e serão sinalizadas com a letra $Q$ (Quaderni del cárcere), seguida pelo número do parágrafo e o número da página. Quando for necessário, indicarei (às vezes mudando-a um 
a este conceito, ele elabora de forma teórica geral uma ideia que Marx desdobra e pressupõe em todas as Teses sobre Feuerbach (1844) e, ao mesmo tempo, repensa o significado dos textos marxianos estimulado pelos eventos históricos de seu tempo, a Revolução Russa e a sua tradução para a experiência dos Conselhos de fábrica em Turim, da qual o próprio Gramsci foi um dos organizadores e líderes políticos mais importantes. Ao mesmo tempo, interpreta estes fenômenos históricos, ajuntando-se com as ideias expressas na linguagem marxiana e leniniana, as quais são as fontes principais da tradutibilidade (como destacará o próprio Gramsci nos parágrafos dedicados a este tema).

Antes de analisar o $Q 8,208$, cabe destacar que a unidade de "teoria" e "prática" é possível porque, segundo o autor dos Cadernos, existe a possibilidade de "traduzir" estes dois "elementos". Por um lado, eles podem ser traduzidos duma maneira parecida, em um certo sentido, com a tradução entre linguagens (em particular a de que trata a ciência chamada linguística histórica, que Gramsci estudou na Universidade de Torino com o Prof. Matteo Bartoli e continuou a estudar no cárcere) ${ }^{2}$; por outro lado, essa tradução implica um trabalho político, no sentido amplo desta palavra, ou seja: um trabalho pedagógico-cultural, que se insere no quadro da transformação política da sociedade; e implica, também, um trabalho político, no sentido estrito, que é necessário para realizar a nova cultura e visão de mundo ou "linguagem", como Gramsci também a chama.

A tradutibilidade nasce absorvendo e fundindo no pensamento marxista essencialmente um paradigma de uma outra ciência, a linguística histórica (seu conceito de língua, linguagem e tradução); mas, obviamente, o paradigma da linguística, ou melhor, todos paradigmas ou fontes que

pouco) a tradução em português dos Cadernos do Cárcere de, C. N. Coutinho (Edição e tradução). L. S. Henriques e M. A. Nogueira (Coedição). Rio Janeiro: Civilização Brasileira, 2001-2006.

2 Entre os linguístas históricos que influenciaram fortemente Gramsci podemos lembrar, por exemplo, os italianos Graziadio Isaia Ascoli e Matteo Bartoli; os franceses Michel Bréal, Antoine Meillet e, indiretamente, Ferdinand de Saussure (cf. LO PIPARO, 1979, p. 85-102); mas também o alemão Franz Nicolaus Finck, que ele traduziu no cárcere. Contudo as ideias de Gramsci sobre a linguagem não são desenvolvidas só a partir de uma reflexão sobre obras de linguística, há outros autores, filósofos, além de Marx e Lênin que o influenciam, mas aqui não há espaço para ampliar esta discussão. 
entram nesta fusão, acabam por ser transformados (aqui, acenaremos apenas para duas destas fontes, embora centrais, e trataremos o assunto de forma muito simplificada). Se nos perguntarmos porque Gramsci indica explicitamente, como fontes da tradutibilidade, apenas Marx (em a Sagrada família e Teses) e Lênin (o que "disse e escreveu" no $Q 7,2,854$ ), uma possível resposta pode ser, como argumentei em um outro ensaio ${ }^{3}$, que, neles, o autor dos Cadernos encontra - embora mais implícita - uma compreensão da linguagem ainda mais profunda que a da linguística histórica (destacando seu papel político, no sentido amplo) e as coordenadas para impostar uma teoria absolutamente original e inovadora sobre as questões linguísticas; mas, acima de tudo, que a teoria marxiana e leniniana não estavam, apesar das diferenças, em contradição com as ideias da linguística histórica (segundo as quais a linguagem é um elemento social e histórico) - como, ao contrário, alguém tentou defender ${ }^{4}$.

\footnotetext{
3 LACORTE, R., 2012.
}

4 Cf. Lo Piparo, F., (1979, p. 263), ainda que neste livro mostre otimamente a centralidade da reflexão sobre a linguagem em Gramsci, Lo Piparo chegará a teorizar o "não marxismo" dele, mesmo a partir desta própria centralidade em conexão com as fontes do revolucionário sardo. Para ele, Gramsci teria prevalentemente desenvolvido o liberalismo aberto contido na teoria linguística de Graziadio Isaia Ascoli, da qual derivaria o conceito de "hegemonia" em relação ao de "prestígio linguístico". Mas isto não bastaria para explicar a gênese deste conceito, como mostraram vários outros estudiosos, entre os quais, por ex., BOOTHMAN, 2004; FROSINI, 2003 e 2010; SANGUINETI, 1981; SCHIRRU, 2005. Contudo, Lo Piparo não considera o papel da tradutibilidade em conexão com a teoria gramsciana da linguagem. Eu acho, ao contrário, que devemos compreender que a teoria gramsciana da linguagem é impensável sem a tradutibilidade, cujas fontes principais, aliás, como explicitamente indicado pelo próprio Gramsci, são Marx e Lênin - as quais, a respeito da ideia da historicidade da linguagem, não estão em contradição com a teoria linguística de Ascoli. Por isso, o alcançado por Lo Piparo é o êxito que se obtém por ele ter escolhido privilegiar umas fontes em lugar de outras e é, portanto, um êxito unilateral, que não é por nada justificado pelos próprios textos, e até por ter deixado de lado as fontes marxiana e leniniana indicadas pelo próprio Gramsci. Esta conclusão extremista pode-se vislumbrar já no livro de 1979 e se torna explícita no artigo: "Studio del linguaggio e teoria gramsciana". In: Revista Critica Marxista. Roma: Editori Riuniti, 1987, n. 2/3, p. 167-75. Para umas interpretações em contratendência se podem ler SCHIRRU, 2005 e alguns dos ensaios incluídos em IVES, P.; LACORTE, R. (Org.), 2010. Ultimamente, Lo Piparo (2010) tentou argumentar a influência de Wittgenstein sobre Gramsci, via Piero Sraffa (amigo de Gramsci e colega de Sraffa na Universidade de Cambridge). Pretendemos tratar disto em um futuro ensaio, por agora, podemos afirmar que, ao ler este novo estudo, o que impacta o leitor é que, para demonstrar a sua tese, Lo Piparo utiliza, entre outros, os textos da Carta para Tânia e o 
A este respeito, o próprio autor dos Cadernos destaca que a "ortodoxia" do marxismo e da filosofia da práxis consiste no fato que ela "basta a si mesma" e não deve ser buscada "nesta ou naquela tendência ligada a correntes estranhas à doutrina original" ( $Q$ 11, 27, 1434 - grifo meu). O estudo das fontes serve para iluminar a biografia intelectual de um autor, mas sua originalidade filosófica não pode ser reduzida a elas. Muito pelo contrário, ela consiste no fato que o autor supera as suas próprias fontes. Spinoza, Feuerbach, Hegel, entre outros, "não são de nenhum modo partes essenciais da filosofia da práxis, nem essa se reduz a elas", pois "o que sobretudo interessa é precisamente a superação das velhas filosofias, a nova síntese, o modo de conceber a filosofia" $(Q 11,27,1436)$. Estas palavras de Gramsci são dedicadas tanto a Marx como a si mesmo. E a tradutibilidade é o "lugar" no qual o pensamento de Gramsci supera todas as suas "fontes": os acontecimentos históricos vividos por ele, Croce, Labriola, Sorel, os pragmatistas, Bartoli, Breál, Ascoli, entre muitos outros, incluindo-se Marx, Engels e Lênin - se bem que estes últimos são constantemente indicados como os fundadores da filosofia que ele mesmo contribui a "desenvolver coerentemente" $(Q 11,27,1436)$ e como os primeiros elaboradores dos germes da tradutibilidade. Desta forma, o autor dos Cadernos coloca-se, ao mesmo tempo, em linha de continuidade ideológica com estes últimos. Pensar que a filosofia de Gramsci possa ser reduzida àquela dos autores liberais significa não ter entendido tudo isso. Pensar que se possa reduzir também à reflexão dos fundadores da filosofia da práxis significaria fazer uma operação anacrônica, levando o "relógio" da reflexão gramsciana para dezenas de anos antes, para linguagens cunhadas para interpretar (e transformar) uma realidade diferente. Cabe levar em conta que entre ele e suas fontes, tem a história ocorrida, além da sua experiência de ação política e a reflexão sobre elas, a qual é também uma reflexão sobre como atualizar e sintetizar ("traduzir") as linguagens das suas fontes, além de conferir seu valor “científico". Pois, este valor depende não apenas da coerência lógica e formal da teoria de Marx, Engels ou

Q 10 II, 9 (que iremos comentar abaixo) tirando, de novo, de sua argumentação o essencial: as considerações do revolucionário sardo sobre a tradutibilidade, comportando-se, portanto, como se Marx e Lênin não tivessem papel central, e demonstrando (involuntariamente) que a sua interpretação continua de forma unilateral. 
Lênin, mas da sua transformação em elemento que estimula a compreender melhor a nova realidade, desenvolvendo as ideias desses autores, e em ideologia, isto é, em elemento que produz efeitos reais transformadores. Com este fim a linguagem teórica deve ser adaptada ativamente à realidade contemporânea, reelaborada e transformada, ou seja, "traduzida" em uma "linguagem" contemporânea (assim aprofundando e acrescentando, sem subverter, seu valor originário). Tudo isto é testemunhado também pelo próprio fato que a tradutibilidade constitui o núcleo teórico do marxismo gramsciano, que deriva e, ao mesmo tempo, desenvolve algo que em Marx e Lênin era apenas implícito. Além disso, Gramsci se preocupa também em estudar e mostrar como a nova síntese, isto é, a filosofia da práxis, nasceu por meio de uma "tradução" (interpretada a partir do modo como a entendiam os próprios Marx e Lênin).

Em Gramsci é a tradutibilidade o critério que fundamenta, ao mesmo tempo, a teoria gramsciana da linguagem e a da política, e, pela tradutibilidade, se compreende como ambas são entrelaçadas como teoria da hegemonia: nesta, o político é "linguístico-simbólico-cultural" e, ao mesmo tempo, o linguístico-simbólico-cultural é "político" - ou seja, elemento de consenso e, ao mesmo tempo, de coerção, como demonstra a teoria da "guerra de posição", a qual inclui a teoria das "estruturas ideológicas". Estas, por sua vez, são as que produzem e difundem as linguagens que influenciam e formam a opinião pública, especialmente nas sociedades moderna e contemporânea de massa ${ }^{5}$. Cabe, portanto, destacar que a própria tradutibilidade nasce essencialmente da fusão - ou tradução - do marxismo e da linguística histórica. De ambos a tradutibilidade considera o lado linguístico e o lado político, mas o primeiro permanece em grande parte implícito e não suficientemente desenvolvido no marxismo (até Gramsci e também depois dele); o segundo, é ainda mais implícito e menos desenvolvido na linguística. Nos Cadernos, porém, por meio da tradutibilidade, tanto a compreensão do primeiro quanto do segundo, apresentam uma evolução teórica. De fato, o marxismo de Gramsci, por ter desdobrado este novo conceito, coloca-se na condição de explicar e justificar teoricamente, através da afirmação do seu caráter concreto (ou

5 Cf., por ex., $Q 1,44,51$ e $65 ; Q 3,49 ; Q 29,3$. 
"objetivo", como diria o Marx da primeira tese sobre Feuerbach), quer dizer, "político", a historicidade da linguagem (enquanto, no âmbito da linguística - histórica ou não - ou existia a simples constatação desta historicidade ou faltava uma explicação que não fosse de caráter metafísico). Além disso, este novo marxismo, ao buscar explicar o que significa o fato de uma linguagem ser expressão ${ }^{6}$ histórica e social, chega a conceber como qualquer atividade humana, que não se manifesta como linguagem no sentido estrito, possa ser também considerada "expressão" e "linguagem", conhecimento e cultura, embora num sentido mais amplo e forte. Isto é, chega a ampliar o próprio conceito de linguagem ${ }^{7}$.

Por outro lado, uma das contribuições fundamentais da linguística histórica para a política e o marxismo consiste em ajudar a entender mais a fundo que todas as ideias são, ao mesmo tempo, linguagem, portanto, também as ideologias, ou seja, o "terreno no qual determinados grupos sociais tomam consciência do próprio ser social, da própria força, das próprias tarefas, do próprio devir", ou, ainda, "momento necessário da subversão da práxis" $(Q 10 \mathrm{II}, 41 \text {, xii-grifo meu })^{8}$. Longe da interpretação do idealismo, do esperantismo ou daqueles que tiveram fé nas línguas fixas e universais (aceita também por muitos membros da Internacional), entre outros, este terreno é agora considerado algo cultural e histórico, como todas as linguagens, que funciona de maneira parecida com elas. Portanto, como todas as linguagens, este terreno deve ser constantemente adaptado à (traduzido da e para a) realidade histórico-cultural presente 9 . Por isso, fazer política implica desenvolver uma consciência profunda deste lado da questão, especialmente em relação ao problema da sua capacidade de comunicar, de ser entendida pelas massas e de influenciar ("pedagogicamente") a opinião pública para educá-la e mudá-la. Isto permitirá a Gramsci inaugurar a sua original reflexão sobre o que hoje se chama de mass media, especialmente em relação à construção e manutenção da hegemonia e do poder. Portanto, do mesmo modo que dilata o conceito de

\footnotetext{
6 Cf. mais abaixo para a definição gramsciana deste termo.

7 Cf., por ex., $Q 3,49, Q 29,4$ e $Q 8169$.

8 Cf., por ex. $Q 1,44,51$ e $Q 10 I I, 44$.

9 Cf., por ex., $Q 7,3 ; Q 7,36$ e $Q 11,16$.
} 
linguagem por meio da tradutibilidade, Gramsci amplia o próprio conceito de política - como também o faz com todos os conceitos tradicionais. Em relação à exigência de ir além dos confins linguísticos no sentido estrito, já existe uma denúncia interna à própria linguística. $\mathrm{O}$ grande linguista francês Antoine Meillet afirmara claramente que "o problema essencial da história das línguas consiste em determinar como os contatos entre grupos sociais diversos se traduzem em fatos linguísticos". Mas os linguistas não queriam se aventurar em tais discussões, pois, "neste terreno, não encontram a precisão e segurança dos seus procedimentos deíticos ordinários". Contudo, "na medida em que visam explicar os fatos, devem sair dos fatos da língua", pois "não podemos nos limitar à linguística pura". Aliás (para citar um outro texto do próprio Meillet), "a língua não existe sem a sociedade, assim como as sociedades humanas não existiriam sem linguagem"10. Além disso, não apenas em Meillet, mas também em âmbito mais amplo da linguística histórica (na França, Alemanha e Itália), chegou-se à consciência de que cada linguagem é uma concepção do mundo (embora menos coerente e homogênea que aquela elaborada pelos filósofos profissionais) e, enquanto histórica e ligada a uma cultura determinada, tem seu próprio jeito de organizar semanticamente a realidade, uma encontrando soluções diferentes em comparação às outras. Isto implicava a insurgência do problema da tradução de uma linguagem para a outra - o qual foi central também para Gramsci e não só nos seus escritos, mas também na sua própria vida. Graças à linguística, Gramsci fará avançar a questão do caráter linguístico das ideias e, graças à reflexão sobre Marx e Lênin, fornecerá à própria linguística a sua resposta e a fará ir além da concepção de linguagem no sentido estrito (só verbal) e ir além da futura semiótica (portanto, sem "sair" da linguagem, como fala, mas provavelmente só no sentido metafórico, o próprio Meillet), mesmo por ter compreendido o caráter político da própria linguagem, superando, desta forma, pelo menos na impostação das questões, os limites da linguística de então e também futura - limites já destacados com grande agudeza por uns dos próprios linguistas, como Meillet. De fato, para impostar a questão da "linguagem" em Gramsci deve-se partir da tradutibilidade. Porém, faltam

$\overline{10}$ Cit. em Lo Piparo (1979, p. 263). 
estudos nesta direção, poucos são os estudiosos informados e conscientes deste problema ${ }^{11}$.

Como observamos, Gramsci, cita explicitamente como fontes da tradutibilidade, apenas Marx e Lênin, embora seja possível acrescentar aqui, de forma simplificada por razões de espaço, além da linguística (e da filologia) histórica, os pragmatistas (citados e, ao mesmo tempo, criticados por ele) e Benedetto Croce (também criticado - cfr. $Q 4,3$, 423). Isto explica-se provavelmente pelo fato de que, como acenamos, nem a linguística histórica nem os pragmatistas colocaram o problema da tradução, acima de tudo como tradução fundamental entre atividades teóricas e práticas (que é o coração da filosofia da práxis) - a qual coloca o caráter político - e por isso histórico - da linguagem e o "linguístico", "simbólico", "expressivo" das atividades práticas e da realidade histórica - enquanto Croce, mesmo reconhecendo-o, rejeitara-o voluntariamente (cf. $Q 4,3,423 ; Q 7,1,852$ ss.).

\section{Aspectos da teorização da tradutibilidade}

É este o tipo de tradução que Gramsci teoriza em vários textos e no Q8, 208 (fevereiro-março 1932) e que o amarra, em termos de débito teórico e ideológico, a Marx e Lênin. Aqui, pela primeira vez nos Cadernos, os dois, como símbolos histórico-teóricos de "teoria" e de "prática", encontram-se ambos juntos como pressupostos necessários e equivalentes para teorizar sobre a tradutibilidade. Depois de ter comentado "a observação feita por Marx na Sagrada família" - considerada como a fonte das Teses pelo autor dos Cadernos - "que a linguagem francesa equivale à linguagem filosófica alemã" ${ }^{2}$, Gramsci propõe a sua interpretação de como esta equivalência

11 Listo aqui alguns dos estudiosos que têm considerado as questões da tradução, da tradutibilidade e da linguagem em Gramsci: BORGHESE; BOOTHMAN; BUEY; FROSINI; GENSINI; IVES; KANOUSSI; DE MAURO; SCHIRRU; TOSEL. A maioria dos estudos destes autores se encontram em IVES and LACORTE, 2010.

12 "Se o senhor Edgar comparar por um momento a igualdade francesa com a autoconsciência alemã, encontrará que o segundo princípio expressa em alemão, isto é no pensamento abstrato, o que o primeiro diz em francês, isto é, na língua da política e do pensamento intuitivo". Tradução minha de ENGELS, F.; MARX, K. La sacra famiglia. A. 
se constitui e deve ser pensada: pode-se afirmar que a teoria equivale à prática, na medida em que a primeira pode se transformar, traduzindo-a, para a segunda e a segunda para a primeira. Ao sintetizar o que, mais em particular, já tratou em outros textos, Gramsci expressa esta ideia da seguinte forma: “[...] a filosofia deve tornar-se 'política', 'prática', para continuar a ser filosofia" ( $Q 8$, p. 1066).

Cabe observar, em primeiro lugar, que só ao tornar-se política, prática (note-se que no texto de Gramsci essas palavras estão entre aspas pois têm contemporaneamente um sentido mais amplo e forte, de "política" como elemento com efeitos organizadores e transformadores da vida) uma linguagem teórica demonstra, para usar as palavras de Marx, sua "verdade", isto é, sua "realidade" e "poder", seu "caráter terreno", ou seja, imanente: de universalidade social e histórica que não reconhece nada de transcendente "mas se baseia toda na ação concreta do homem, o qual para suas necessidades históricas opera e transforma a realidade" ( $Q 5$, 127, 657; CC, 1999 , vol. 3, p. 216-223) ${ }^{13}$. Isto é ainda mais claro no caso da atividade política, embora seja menos claro que ela não apenas seja elemento transformador do mundo (quando e enquanto os tem), mas tem, ao mesmo tempo, efeitos de "conhecimento" e, por isso, pode se tornar linguagem teórica e filosófica (verbal, pois já é algo "linguístico", que, porém, se expressa "praticamente"). Contudo, já enquanto tal, nunca é atividade prática esvaziada de pensamento, mas sempre práxis, ou seja, conjunto prático-teórico em movimento.

Em segundo lugar, cabe explicar que se tornar, no texto do $Q 8$, 208 acima, significa traduzir. Este verbo, de fato, em vários textos dos Cadernos, é usado segundo um significado próprio, "técnico", metafórico ${ }^{14}$ em relação aos significados passados, mas que coincide com um novo que visa expressar as novas práticas e a visão de mundo do movimento

Zanardo (Org.). Roma: Editori Riuniti, 1967, p. 47. Conjecturei sobre uma forte ligação entre o uso de "expressão" em Marx e Gramsci em relação à concepção de "imanência" em um outro ensaio (cf. LACORTE, 2012).

13 De agora em diante, com CC será indicada a edição brasileira dos Cadernos do Cárcere organizada por, C. N. Coutinho; Coedição, , L. S. Henriques;, M. A. Nogueira. RJ: Civilização Brasileira, 2001-2006.

${ }^{14}$ Cf. FROSINI, 2010, cap. II. 2. E cfr. $Q$ 11, 24, 1427. 
comunista internacional15. Como sinônimo da expressão "deve ser traduzido" se entende bem se lermos a citação do $Q 8,208,1066$ junto com uma do $Q 10 \mathrm{I}, 5,1218$, onde o autor dos Cadernos fala da necessidade de "traduzir em termos 'populares", a filosofia. Portanto, a frase do $Q$ 8, 208, sintetiza teoricamente, através de um único conceito, o de tradutibilidade, dois lados do mesmo processo político-histórico e cultural, o qual, nos seus vários aspectos, é analisado pelo autor dos Cadernos em vários parágrafos ${ }^{16}$.

Em terceiro lugar, cabe destacar que esta tradução não é apenas um processo lógico-linguístico no sentido estrito, pois, ao mesmo tempo, ela afeta a realidade; e isso ocorre entre linguagens que se baseiam em atividades diferentes - por exemplo, a política na França e a teórica na Alemanha ${ }^{17}$ - as quais: 1) coincidem com as capacidades prático-teóricas particulares que cada comunidade humana consegue desenvolver historicamente em um dado espaço-tempo; 2) dependem e contemporaneamente constituem, produzem, estas realidades - e, por isso, são atividades elas mesmas; 3)

15 Gramsci usa muito este verbo neste sentido novo. Cf., por ex., o importantissimo $Q 10$ II, 44.

16 Em muitos desses parágrafos é presente implícita ou explicitamente o conceito de "catarse", com o qual Gramsci indica: "a passagem do momento meramente econômico (ou egoístico-passional) ao momento ético-político, isto é, a elaboração superior da estrutura em superestrutura na consciência dos homens. Isto significa, também, a passagem do 'objetivo ao subjetivo' e da 'necessidade à liberdade'" ( $Q 10 \mathrm{II}, 6, i)$; mas cf. já, por ex., $Q 1$, 43; $Q 1$, 44, 51; $Q 3,48 ; Q 4,3 ; Q 4,33 ; Q 8,169 ; Q 8,195 ; Q 11$, 12, etc. Gramsci coloca estas frases entre aspas pois, como veremos, para a tratutibilidade, cada atividade humana é sempre um conjunto objetivo-subjetivo, prático-teórico, necessário-livre, em movimento, no qual o que pode historicamente variar é o grau de "subjetividade" (ou de "objetividade"). Uma atividade humana pode ser relativamente mais "objetiva" (ou "prática" ou "necessária") em relação a uma outra que, no espaço-tempo, desenvolveu mais seu lado "subjetivo", "teórico", "superestrutural". Não existe nada, no campo da práxis humana, que seja absolutamente objetivo ou subjetivo, pura estrutura ou pura superestrutura, etc. Ao longo da redação dos Cadernos, paralelamente ao desenvolvimento da tradutibilidade, Gramsci desenvolve, também, um novo modo de formular as várias questões e assim supera o velho modo de teorizar sobre a realidade através de uma linguagem dicotômica. Quando a conserva é porque pode servir do ponto de vista da análise ou didático e, na maioria dos casos, põe entre aspas os vários termos que a "Tradição Dicotomizadora Ocidental" (TDO) separa, para indicar que ele os interpreta de uma maneira muito diferente.

${ }^{17}$ Gramsci explica isto no $Q 11,48,1470$ (reescritura posterior do $Q 8,208$ ), afirmando que se trata de "linguagens de tradição diferente, formadas com base em atividades caraterísticas e particulares" (Cf. CC, 1999, v. 1, p. 187). 
coincidem pelos efeitos reais que produzem: não antes de produzi-los; isto é, porque produzem efeitos "fundamentalmente parecidos"; 4) devem necessariamente ser traduzidas por causa do fato que são diferentes; mas, quando e enquanto, a tradução revela que são equivalentes, graça à equivalência dos seus efeitos reais, mostra que elas são substituiveis ou traduziveis reciprocamente.

Em quarto lugar, cabe explicar, mais precisamente, que a primeira parte da frase gramsciana do $Q 8,208$ citada acima ("a filosofia deve tornarse 'política', "prática"') refere-se ao alcance "prático" da teoria, a qual, quando e enquanto é traduzida para a prática demonstra ser uma forma de atividade prática por si mesma, ou melhor: práxis. Neste sentido, Gramsci já disse que, ao realizar politicamente a hegemonia na Rússia, Lênin havia, ao mesmo tempo, realizado a teoria de Marx. Contudo, essa "tradução" não deixava tal teoria sem mudanças, era também uma inovação, uma implementação crítica de tal teoria mesma. Como ele escreverá mais adiante: "A hegemonia realizada significa a crítica real de uma filosofia, a sua real dialética" $(Q 7,33,882)$. Ademais, Gramsci afirmará mais tarde - pressupondo, evidentemente, seu desenvolvimento paralelo do conceito de tradutibilidade - que ter consciência mais ou menos profunda das relações necessárias “já as modifica [...]. Neste sentido, o conhecimento é poder" (Q 10 II, 54, 1345, fevereiro 1933; CC, 1999, v.1, p. 414). E, de fato, a segunda parte da frase ("para continuar a ser filosofia") refere-se ao alcance "teórico", "gnosiológico" ou "teorético" da prática, conforme o que Gramsci escreverá, por exemplo, no $Q 10 \mathrm{I}, 12$ :

Ilitch teria feito progredir [efetivamente] a filosofia [como filosofia] na medida em que fez progredir a doutrina e a prática política. A realização de um aparelho hegemônico, enquanto cria um novo terreno ideológico, determina uma reforma das consciências e dos métodos de conhecimento, é um fato de conhecimento, um fato filosófico (ibidem, 1250; CC, 1999, v.1, p. 320 - grifo meu; Cfr. $Q 4,45,471)^{18}$.

${ }_{18}$ Cf. LACORTE, 2009, p. 72s. 
Mas isso significa também que o "momento" "prático" é, ao mesmo tempo, "teórico", pois é nele que a teoria e os seus métodos se desenvolvem graça às "experimentações" por meio das quais se aprofundam, acrescentam e corrigem - e, para Gramsci, estes experimentadores sociais são os intelectuais coletivos, os partidos políticos $(Q 11,12,1387)$. E no $Q$ $10 \mathrm{II}, 31$, ele escreve: "[...] ao trabalhar praticamente para fazer história, faz-se também filosofia 'implícita', que será 'explícita' na medida em que filósofos a elaborem coerentemente [...]” (ibidem, 1273; cfr. CC, 1999, v. 1, p. 343; cfr. $Q 3,48,333$ ). Contudo, antes destas linhas, Gramsci havia esclarecido muito bem que devemos sair da concepção tradicional segundo a qual a filosofia (e podemos acrescentar as linguagens teórico-científicas em geral) se encontraria só no campo da especulação teórica. Ao contrário, a prática não apenas não é "cega", vazia de pensamento, mas é a forma real, concreta da filosofia: “o 'conhecimento' [...] só [...] na atividade prática é 'real conhecimento' e não 'escolasticismo"' $(Q 10$ II, 31, 1271). Em outras palavras, através do conceito de tradutibilidade, se demonstra e explica que (e em que sentido) práxis não significa prática. Ou seja, não significa prática esvaziada de pensamento, ideologia, sentimentos, etc., isto é, algo oposto a teoria. Mas, desta forma, se demonstra e explica também em qual sentido a própria teoria não significa algo separado e oposto à prática.

Por isso, através da tradutibilidade, chegamos a compreender como, nos Cadernos, Gramsci supera progressivamente, até em relação as suas próprias formulações linguístico-teóricas, a separação tradicional entre teoria e prática; e como o que tradicionalmente se chama de prática, na realidade, sempre é uma determinada teoria em seu desenvolvimento, isto é, expressa, ao mesmo tempo, uma determinada concepção do mundo; e o que se chama de teoria é, ao mesmo tempo, uma determinada prática que se está elaborando, potencializando e transformando. Por isso, neste caso, podemos afirmar que ela expressa, ao mesmo tempo, uma determinada prática. Em ambos os casos, trata-se sempre de um único conjunto práticoteórico, ou seja, de um objeto-sujeito, uma estrutura-superestrutura, etc., em movimento e a um certo grau (quantitativo e qualitativo) do seu devir histórico. Isto é o que, por exemplo, podemos ler em uma das formulações gramscianas mais maduras: 
a ciência não é essa mesma "atividade política" e pensamento político, na medida em que transforma os homens, os torna diferentes do que eram anteriormente? [...] Contudo, deve-se ver se se trata de criação "arbitrária" ou racional, isto é, "útil" aos homens para ampliar o seu conceito da vida, para tornar superior (desenvolver) a própria vida $(Q$ $15,10,1766$ ).

Cabe, enfim, observar que o próprio conceito de práxis éa "tradução" gramsciana - à luz da própria tradutibilidade e dos acontecimentos históricos presentes (a Revolução Russa e a experiência dos Conselhos de fábrica em Turim $)^{19}$ - do que se encontra na fonte principal desta ideia nos Cadernos, as Teses sobre Feuerbach de Marx ${ }^{20}$. Este último, em lugar de práxis, utiliza também a expressão "atividade humana" "sensível", "objetiva". E no $Q 4$, 37, falando do conceito de práxis marxiano, Gramsci o interpreta como "atividade do homem (história) em concreto" $(Q 4,455)$, isto é, na linguagem de Gramsci, como algo que tem "efeitos reais". Como se vê, é a tradutibilidade (que já estava sendo desenvolvida quando o autor dos Cadernos escreve este parágrafo) que ilumina a compreensão, já exposta na primeira tese sobre Feuerbach, de que o "objeto" não é apenas o "sensível"; mas objetiva ou sensivel é também a atividade do "sujeito", do "pensamento" e, portanto, "objeto" é entendido ao mesmo tempo "subjetivamente"; então, "objetivo" significa também algo que tem uma eficácia "prática" ou "política", pois seus efeitos transformamrevolucionam o mundo. De fato, à medida que se põe como "objetiva" ou "sensível" a própria "atividade humana", deve ser interpretada como "objetivo" ou "sensível" também o "(modo de proceder) teorético" ("theoretische Verhalten"), pois o próprio pensamento é atividade humana, uma das atividades humanas. Assim, não apenas qualquer atividade, mas nem sequer a peculiar do pensamento, é "ato puro" (isto é, depurado de qualquer diferença, matéria, circunstância, etc.), como o entendia o filósofo

\footnotetext{
${ }^{19}$ Cf., sobre este aspecto em particular, LACORTE; SILVA; PAIVA; LEITÃO, 2013.

$20 \mathrm{O}$ autor dos Cadernos traduziu as Teses no cárcere do texto original em alemão, mas elabora, ao mesmo tempo, o uso do termo marxiano práxis assim como foi interpretado anteriormente também pelo marxista italiano Antonio Labriola. Cf., por ex., $Q 4,3$ e $Q 3$, 31, os estudos de FROSINI, 2010, cap. 1, e de LOSURDO, 1990.
} 
idealista Giovanni Gentile, pois, na medida em que é práxis, é sempre "ato "impuro", quer dizer: um conjunto de elementos heterogêneos em movimento. Só ao raciocinar desta forma chega-se também a compreender o significado e a "importância da atividade 'revolucionária', da atividade prático-crítica" ( $Q 2355)$.

Após um ou dois meses depois de ter escrito o $Q 8$, 208, Gramsci dirá, de forma mais geral, que é possível demonstrar que existe uma ligação necessária não apenas "entre as diferentes atividades científicas" mas, ao mesmo tempo, "entre atividades cientificas e atividades práticas" 21 . Trata-se das linhas de uma carta para Piero Sraffa (ou ainda para Palmiro Togliatti) ${ }^{22}$, via cunhada Tatiana (chamada mais frequentemente Tania), escrita no fim de maio de 1932, na qual Gramsci tenta esclarecer para o grande economista (e companheiro de partido) o conteúdo de algo que já escrevera no $Q 10$ II, 9, 1247, no qual em lugar de "atividades" (palavra usada nas Teses por Marx, que ele traduziu no cárcere) usa a palavra "linguagens" (o que demonstra, na elaboração da tradutibilidade, a influência da linguística e não só de Marx, embora este último também, na Sagrada família, "fonte" das Teses, refira-se à política francesa e à autoconsciência alemã como a duas linguagens). E isto, aliás, acontece em vários outros apontamentos anteriores ou contemporâneos, nos quais trata implícita ou explicitamente da tradutibilidade ${ }^{23}$. Por meio da leitura

21 GRAMSCI, A. Lettere dal carcere. CAPRIOGLIO, S.; FUBINI, E. (Org.). Torino: Einaudi, 1965, p. 582, citado, de agora em diante, com a sigla $L C$, seguida pelo número da página, e traduzido por mim. Estas afirmações se encontram na carta para Tania de 30 maio de 1932, na qual Gramsci conjetura que Marx teria derivado a concepção da imanência da sua interpretação dos conceitos de "homo economicus" e de "mercato determinado" de David Ricardo, e da síntese deles com as "linguagens" política francesa e filosófica alemã - síntese que ele mesmo chama "tradução".

22 Conforme afirmado pelo presidente do Instituto Gramsci italiano, Giuseppe Vacca, em sua palestra, durante o Simpósio Internacional de Filosofia Política "A Atualidade de Marx e Gramsci" na Filosofia Política, 25 a 29 de novembro de 2013, na Universidade Federal de Uberlândia (UFU) - Brasil.

23 Que o nexo entre prática e teoria reenvie à tradutibilidade, é o que se pode deduzir da referência sucessiva de Gramsci a um texto de Marx e Engels da Sagrada família (citado acima), mas as linhas às quais Gramsci se refere foram escritas por Marx. A estas ele faz referência já em outros parágrafos dos Cadernos em relação à sua teorização. Na Carta citada, Gramsci escreve: "Na Sagrada Família se vê como este nexo posto por Hegel entre 
comparada da carta e do $Q 10 I I$, 9, entre outros parágrafos, pode-se entender que, nos Cadernos, os dois termos e os conceitos correspondentes formam uma incindível relação dialética, a qual remete a uma relação real. Aqui "atividade" significa atividade humana histórica, organizadora-transformadora, em uma palavra, práxis, a qual coincide com tudo o que tem efeitos concretos, enquanto atividade que consegue (e deve) tornar-se historicamente permanente. Neste sentido, podese falar de "atividade racional" como expressão que indica algo não "arbitrário" enquanto aceito e atuado com regularidade pelas massas (e, portanto, não propriamente no sentido de "atividade lógica", "raciocínio", "pensamento" etc.) ${ }^{24}$. Desta forma, posta politicamente e historicamente a sua "racionalidade", qualquer atividade humana (práxis) expressa e simboliza algo determinado, e, portanto, é "linguagem" - também no sentido de que pode ser "lida", interpretada, compreendida e, por isso, traduzida e conhecida; mas, ao mesmo tempo, qualquer linguagemexpressão-símbolo ("racional") é atividade transformadora do mundo, ou seja, práxis. Portanto, práxis é o conceito mais geral que sintetiza a compreensão de todas as atividades humanas racionais, incluídas as linguísticas e simbólicas, como algo que tem uma eficácia real e, vice-versa, da prática como algo que tem contemporaneamente efeitos "teóricos" ou de conhecimento. Daqui, também o caráter estratégico ou tendencialmente estratégico da práxis, quer dizer, de um determinado conjunto de atividades humanas prático-teóricas em movimento que se universaliza ou tenta progressivamente se universalizar socialmente e historicamente, através de uma série de traduções prático-teóricas, até o ponto de se tornar não só o elemento que pode dar o impulso a uma dialética real, mas que pode conquistar a hegemonia e até construir uma nova civilização.

a atividade política francesa e a filosófica alemã tenha sido apropriado pelos teóricos da filosofia da práxis" ( $L C$ 582).

${ }^{24}$ Cf., por ex., $Q 6,10$ e $Q 11,59$. “[...] A cada momento do desenvolvimento histórico há luta entre racional e irracional - entendido o irracional como o que não triunfará em última análise, nunca se tornará história efetiva, mas que em realidade é também racional, porque é necessariamente ligado ao racional, sendo um momento imprescindível dele [...] Só a luta, através do seu êxito, e nem sequer do seu êxito imediato, mas através do que se manifesta em uma permanente vitória, dirá o que é racional o irracional, o que é 'digno' de vencer, pois continua, do seu jeito, e supera o passado" $(Q 6,10,689-90)$. 
É na tradução entre "teoria" e "prática" - entre atividades diferentes que erroneamente a "Tradição Dicotomizadora Ocidental" (TDO) separa e considera em contradição - e só dentro dessa forma peculiar de tradução - que emergem analogias profundas que levam à tona a composição histórica de uma determinada práxis, ou seja, da própria atividade humana nas suas configurações históricas. Esta atividade - ou conjunto dialético de atividades históricas - se desenvolve e expressa (ou pode se desenvolver e expressar) de várias formas: tantas quantas são as diferentes atividades que a(s) constituem, isto é, as que os homens se tornam capazes de gerar historicamente. As fundamentais - que sintetizam de forma lógica uma expressão da histórica divisão do trabalho - são a "prática" e a "teórica". A filosofia da práxis mantém, até um certo ponto, esta distinção entregada pela TDO, mas a interpreta como distinção "analítica", "didática" ou "metodológica" e não "orgânica" $(Q 7,21)$, real ou metafísica, pois a tradução que ela faz mostra que não há duas substâncias realmente diferentes que correspondem a teoria e prática, e sim que qualquer atividade humana "racional" é sempre um conjunto prático-teórico, embora em graus diferentes de composição "teórica" (ou "ideológico-prática"), conforme seu "desenvolvimento" histórico. Isto significa que, através da tradutibilidade, nos Cadernos, se redefinem e resignificam todos os conceitos tal como pensados pelo senso comum e pela tradição (prática, teoria, tradução, linguagem, filosofia, política, matéria, espírito, Estado, etc.).

\section{A tradutibilidade e o significado do termo "expressão" 25}

O mesmo conceito encontrado no $Q 8,208$ aparece já no $Q 7,45$ (fevereiro-novembro de 1931) e, embora não explícito, o que Gramsci escreve neste parágrafo é uma definição importante da (e que ajuda a entender melhor a) tradutibilidade: afirmar que uma filosofia "é expressão de uma sociedade" significa não só que ela depende de uma determinada realidade (como o efeito da causa, mecanicamente), como pensavam

25 Esta parte do ensaio é uma reelaboração de uma parte do que tratei em LACORTE, 2012. 
muitos marxistas (da Segunda e Terceira Internacional), mas também que ela "conquistou" uma "eficácia prática": "a medida em que ela reage é [...] a medida de sua importância histórica, de não ser ela 'elucubração' individual, mas sim 'fato histórico',' (Q 7, 45, 894; CC, 1999, p. 249-grifo meu). Contudo, ao considerar o que ele escreve nos textos comentados mais acima, pode-se perceber que isto vale não apenas no caso da filosofia como linguagem particular, mas para todas as linguagens e atividadeslinguagens não arbitrárias ou racionais, como é confirmado também por um texto posterior, intitulado Tradutibilidade das linguagens cientificas, no qual o autor dos Cadernos generaliza ulteriormente o discurso sobre a capacidade hegemônica da filosofia, estendendo-o a todas as relações de conhecimento: "a filosofia da práxis concebe a realidade das relações humanas de conhecimento como elemento de 'hegemonia' politica" ( $Q 10$ II, 6, iv, 1245, abril 1932; CC, 1999, v.1, p. 315 - nota-se o uso explícito da palavra "hegemonia" que testemunha, cada vez mais, do peso de Lênin na formulação da tradutibilidade); mas - sempre conforme o desenvolvimento deste conceito alcançado nos textos de 1932 citados acima - pode-se acrescentar que ela concebe, ao mesmo tempo, a realidade das relações prático-político-hegemônicas como elemento de conhecimento.

Além disso, cabe notar: 1) que, na frase do $Q 7,45$, os verbos "conquistou" e "reagir" equivalem a "se tornar" da frase do $Q 8,208$, 1066 citada acima (no primeiro parágrafo Gramsci afirma que a filosofia "conquista" uma eficácia prática, no segundo que "se torna" prática; no "conquistou" percebe-se ainda o eco da realização da hegemonia na Rússia, o qual depois é, digamos assim, catartizado no mais descritivo "se tornar" conforme o momento da teorização, mas o significado é o de uma filosofia que "se traduziu" em realidade). Este uso é peculiar, "técnico" e, embora conservando-o, vai metaforicamente além daquele tradicional e comum, implicando a ideia de que a tradução da teoria para a prática e vice-versa demonstra, consideradas as devidas diferenças, o alcance, a mesmo tempo, mais amplo de cada uma, em comparação com as que interpreta a TDO, e que a realização da equivalência entre as duas é um processo prático-teórico no qual uma comunidade de seres humanos deve sempre construir, através de um trabalho pedagógico-cultural-político, o termo "prático" equivalente ao "teórico" e vice-versa, segundo um 
movimento contínuo que, se interrompido, acaba enfraquecendo ou mesmo comprometendo irremediavelmente a ação e o desenvolvimento de uma determinada práxis. Neste movimento, a teoria se torna elemento concreto (história) através da política, enquanto a prática se elabora e potencializa, tornando-se mais concreta, por meio da elaboração cultural-teóricalinguística ${ }^{26}$; 2) que o conceito de tradutibilidade está fortemente amarrado a um certo uso, de novo "técnico" e metafórico, do termo "expressão", ou melhor, a uma família de termos e expressões (entre os quais, por exemplo, "manifestar", "manifestação", já no $Q 1,44,54$; "se tornar", nos $Q 4,3$, 423, $Q$ 6, 10, 691, $Q$ 8, 208 (explicitamente sobre a tradutibilidade), $Q$ 9, 63, $Q 10 \mathrm{II}, 44$, entre outros; "expressar" e "conquistar" no $Q 7,45$, e até os próprios "refletir", "reflexo", respectivamente nos $Q 1,44,51 \mathrm{e}$ $Q 7,35,886$, no qual "reflexo" é sinônimo de "expressão" e não viceversa $)^{27}$, usados em vários textos dos Cadernos no sentido novo e peculiar de atividade humana que tem uma eficácia prática, transformadora, na medida em que se torna fenômeno concreto, "fato histórico". O que demonstra contemporaneamente que, nesta obra de Gramsci, este conceito é muito difundido, usado - mais do que aparece a um olhar superficial; 3) que, além da possiblidade de criar os novos, todos os conceitos-termos tradicionais vão ser resignificados e recriados por meio de traduções que os (re-)constroem de acordo com a nova linguagem-concepção do mundo em construção, entendida como expressão linguístico-teórica do movimento real de grupos sociais subalternos.

${ }^{26}$ Cf. p. ex. $Q 1,43 ; Q 3,48 ; Q 11,12 ; Q 15,10 ; Q 15,22$.

27 "Que a dialética hegeliana tenha sido um reflexo destes grandes nós históricos e que a dialética, de expressão das contradições sociais [...]" (Q 7, 35, 886-grifo meu). Aqui, está claro que o primeiro termo é usado no sentido do novo significado do segundo; enquanto, no $Q$ 1, 44, 51, que "refletia", na frase "A linguagem dos jacobinos, a sua ideologia, refletia perfeitamente as necessidades da época, conforme as tradições e a cultura francesa", signifique 'expressava', no sentido que encontramos no $Q 7,45$, é o que se deduz ao ler o que Gramsci escreve nas linhas sucessivas. Nelas, de fato, ele argumenta como esta linguagem teve um papel real, ativo e reativo, pois, ao responder as suas necessidades reais, mobilizou ideologicamente os camponeses e unificou a população de toda França e foi, portanto, decisivo para mudar as correlações de força a favor da burguesia francesa, a qual assim conquistou a hegemonia (cf. Q 1, 48, 61); mas está claro também ao considerar a referência à Sagrada família, entre parênteses no $Q 1,44,51$, que indica a ligação entre o significado de "refletia" e a tradutibilidade (por meio da qual, de fato, se pensam as linguagens racionais como elemento de hegemonia), embora ainda implícita. 
Cabe destacar melhor que o significado das próprias traduções nunca é meramente linguístico. Como parte de um processo "molecular", que envolve uma enorme quantidade delas, na medida em que conseguem tornar uma (nova) filosofia (expressão das novas necessidades, sentimentos, conhecimentos dos subalternos) para um elemento que estimula a ação, mudando o jeito de pensar e sentir (a "linguagem" - $Q 10$ II, 44, 1330) de inteiros estratos sociais, as traduções acabam por mudar também o comportamento dos indivíduos como indivíduos e como massa, a ação deles e as suas finalidades e, ao longo do tempo, através de traduções entre culturas diferentes, pode transformar toda uma civilização. Disto se pode deduzir que a própria tradução revela a dimensão mais profunda - sempre política e não apenas morfológica e sintática - da linguagem, ou melhor, que a própria dimensão morfológica, sintática e gramatical, assim como a expressão entendida no sentido literal, é, ao mesmo tempo, atividade humana transformadora, ou seja, "momento" de um devir mais vasto, ao mesmo tempo político e histórico ${ }^{28}$. Isto quer dizer que a tradução literal remete àquela histórico-política; e deve-se, portanto, distinguir pelo menos entre um primeiro nível ou "grau" mais "superficial", no qual o que se traduz leva a compreender melhor uma determinada realidade (mas aqui quem "compreende" já muda os seus comportamentos, e, por isso, há já mudança nas práticas, ainda que em âmbito social e cultural limitado), e um segundo nível, mais "profundo" 29 , no qual o que é traduzido se universaliza socialmente e culturalmente, pois muda não só o jeito de sentir e de pensar, mas também a "prática" de inteiras massas humanas. Neste sentido, para Gramsci, quando se traduz, traduz-se também a prática e não apenas a expressão linguística que corresponde a uma prática determinada: as revoluções ativa francesa e passiva alemã, e ainda outras sucessivamente, têm progressivamente difundido não apenas a ideologia

\footnotetext{
28 Também sobre a própria gramática, Gramsci é claro quando pergunta se ela serve "para fazer a história de um aspecto da civilização ou para transformar um aspecto da civilização" (Q 29, 1, 2342; meu grifo).

29 Cf. BOOTHMAN, 2004, em part. p. 73-78. Superficial/profundo corresponde aqui à relação sentido estrito/amplo ilustrada acima neste ensaio e ligada ao uso gramsciano da tradutibilidade ao pensar ou elaborar os vários conceitos, assim necessariamente resignificando-os.
} 
liberal (e neoliberal), mas também as práticas que correspondem a ela em quase todo mundo. Por isso, a tradução no sentido estrito, sempre pressupõe umas afinidades mais profundas entre culturas, entre práticas humanas, as quais, então, são elas também sempre, ao mesmo tempo, "linguísticas".

Neste quadro, cada vez mais desenvolvido a partir da temporada que começa acerca do fim de 1930 e prossegue nos anos seguintes, Gramsci retoma com mais intensidade a reflexão sobre o significado da obra de Lênin, ou seja, sobre a "tradução" da filosofia de Marx para a política, a ideologia ${ }^{30}$, mais compreendendo qual é o valor da teoria, do saber e, portanto, chega mais próximo do significado da equivalência já indicada pelo revolucionário alemão. Por isso não é casual: 1) que já no $Q 7,1-$ escrito antes de $Q 7,45$, em novembro de 1930 - aberto com uma reflexão sobre a tradutibilidade, encontra-se, no final, um comentário de Gramsci sobre a terceira tese de Marx, em particular sobre o significado da expressão "educação do educador" (isto é, a transformação do ambiente, da realidade histórica e natural, pelo homem), que segundo o autor dos Cadernos consiste no fato de que a "estrutura" não é "algo imóvel", mas "realidade em movimento", pois tem a "superestrutura" que "reage dialeticamente sobre a estrutura e a muda" (ibidem, 854); cabe notar que ao copiar mais tarde, em junho-agosto 1932, esta linha no texto C correspondente, em lugar de "superestrutura" se encontra uma formulação mais realística: "reação ativa do homem sobre a estrutura" (Q $10 \mathrm{II}, 40,1300)$, pois o autor dos Cadernos bem sabe - porque isto mesmo é o que a tradutibilidade visa esclarecer - (que não existem superestruturas ou linguagens que reagem sobre o ambiente separadamente dos seres humanos históricos e que fazem sentido por si mesmas); 2) que no parágrafo sucessivo, $Q 7,2$ (escrito no mesmo período), Gramsci cita pela primeira vez Lênin como fonte da tradutibilidade $^{31}$ e se refere ao problema da "tradução" do "russo" para as outras "línguas europeias" como questão de hegemonia, ou seja, da difusão da hegemonia comunista nos países da Europa Ocidental durante os anos 1920, o qual remete ao da tradutibilidade (como comprova o texto $\mathrm{C}$ correspondente, que abre a seção sobre o mesmo tema no Caderno

${ }^{30}$ Cf. $Q 7,1,854 ; Q 7,19$ e $Q 7,21 ; Q 7,33 ; Q 7,35$, entre outros.

31 Se bem que, como argumentei em LACORTE, 2009, a presença implícita de Lênin em relação à tradutibilidade pode-se detectar já nos Cadernos, em especial no $Q$ 1, 43 . 
11); 3) que o $Q$ 7, 3 (também escrito em novembro de 1930) seja sobre a "historicidade das linguagens", a qual, podemos agora deduzir melhor, depende da medida em que elas reagem ("politicamente") sobre a realidade, como bem perceberemos se ligarmos todos esses textos aos $Q$ 7, 45 e $Q 8$, 208 (e a outros, como veremos).

Contudo, no $Q 7,45$, o autor dos Cadernos acrescenta, a respeito dos $Q 7,1, Q 7,2, Q 7,33$, uma consideração crucial em sintonia com a sua reflexão sobre a ideologia e a política, pois neste parágrafo consegue formular a distinção entre filosofia da práxis e as filosofias tradicionaisabstrações-individuais. Quer dizer, frente à questão sobre o valor da teoria, encontra finalmente a maneira de contrastar a tese idealista (apriorista) da realidade do pensamento, de modo a não desvalorizar contemporaneamente a sua (relativa) autonomia, como acontecia no caso do materialismo tradicional. A realidade, a eficácia concreta do pensamento não é dada $a$ priori, nem é eterna; não é uma caraterística intrínseca dele, mas depende da "medida em que", isto é, enquanto e quando, por meio da atividade de determinados seres humanos, "reage" (politicamente) sobre a realidade e se torna "história". Por isso, contra Benedetto Croce, Gramsci desenvolve uma ideia graça à qual legitimamente se pode e deve falar de um "universal" que tem graus de generalização social e cultural ou de individuação coletiva e, portanto, de algo "conceptual" que tem uma "hegemonia política" ( $Q$ $10 \mathrm{II}, 6, i \mathrm{v}, 1245$ ) mais ou menos extensa. De fato, no $Q 7,45$, como em muitos outros textos, Gramsci fala sobre uma linguagem particular, a linguagem filosófica, que para ele é a forma mais "alta" da ideologia (da "prática"), enquanto é um tipo de linguagem que pode elaborar a "prática" e a realidade de uma forma mais coerente e homogênea, para torná-la universalmente hegemônica através de seus "efeitos organizadores" $(Q 1$, $43,33)$ e transformadores.

Sempre neste quadro, no $Q$ 9, 63 (julho-agosto 1932), Gramsci tentará uma elaboração ainda mais geral do conceito expresso nos $Q 7$, 45 e $Q 8,208$ e afirmará que a prova da universalidade de uma verdade ou linguagem teórica "consiste [...] no que ela se torna": isto é, no "estimulo a conhecer melhor a realidade efetiva em um ambiente diferente do no qual foi descoberta" e no "se incorporar nesta" mesma realidade "como se fosse a expressão original" dela, pois a sua universalidade consiste em se 
tornar realidade efetiva e não só na "sua coerência lógica e formal" ( $Q 9$, 63, 1134; CC, 1999, v. 1, 256 - grifo meu). Não é portanto correto "tratar as questões assim chamadas teóricas como se tivessem um valor em si mesmas, independentemente de qualquer prática determinada" $(Q 9,63$, 1133; CC, 1999, v. 1, 255). O pensamento não nasce por partenogênese, isto é, "[...] deve sempre valer o princípio de que as ideias não nascem de outras ideias, mas são expressão sempre renovada do desenvolvimento histórico real" ( $Q$ 9, 63, 1134; CC, 1999, v. 1, 256 - grifo meu). Em outras palavras, a tradutibilidade é sempre tradutibilidade entre expressões que, enquanto tais, são realidades efetivas (cabe lembrar que também o pensamento é realidade efetiva, práxis, quando e na medida em que se torna real, norma de ação). Isto implica dizer que qualquer tradução, no sentido estrito, sempre pressupõe esta tradução fundamental entre prática e teoria, realidade e linguagem, pois é por meio dela que os significados se realizam, ou seja, tornam-se aqueles elementos culturalmente e historicamente permanentes usados diariamente por uma determinada comunidade humana. De fato, é só depois de ter conferido o tipo de relação entre as realidades efetivas produzidas que se pode estabelecer a efetiva igualdade (ou menos) entre as ideias ou linguagens correspondentes. É isto que parece significar a frase de Gramsci: "Igualdade de realidade efetiva determina identidade de pensamento e não vice-versa" $(Q 9,63,1134, C C$, 1999, V. 1, 256) - a qual não se deveria interpretar como uma expressão do determinismo, economismo, ou pior, mecanicismo do autor dos Cadernos. Muito pelo contrário. O que é confirmado também pelo fato de essa frase corresponder a uma formulação da tradutibilidade: com efeito, é parecida com a que se pode ler no $Q 8,208,1067$, que - "duas estruturas símiles têm superestruturas equivalentes e traduzíveis reciprocamente" -, embora a do $Q 9,63$ seja formulada por um grau de universalidade e abstração muito maior (e é por causa da forma não muito clara na qual este conceito está formulado que, talvez, Gramsci não irá copiá-la nem retomá-la nestes próprios termos em outros textos). Por isso, é possível concluir que "expressão" no sentido ordinário ou literal (por exemplo, "estado", assim como qualquer outra palavra ou expressão) implica sempre expressão no sentido mais forte e amplo. Quer dizer, o valor histórico e cultural de uma expressão depende do seu traduzir-se ou incorporar-se na realidade, de 
poder ser expresso "nas linguagens das situações particulares" $(Q 9,63$, 1134).

Há, agora, bastante elementos para afirmar que se coloca neste quadro também a afirmação anticrociana da historicidade da linguagem que se encontra em um texto anterior, segundo a qual as próprias inovações linguísticas "não são individuais (como ocorre na arte)", mas de "toda uma comunidade social que inovou sua cultura, que 'progrediu' historicamente: naturalmente, também estas se tornam individuais, mas não do indivíduoartista, e sim do indivíduo - elemento histórico-[cultural] completo, determinado" (Q 6, 71, 738, dezembro 1930 - março 1931; CC, 2002, v. 6 , p. 197). Essa mesma ideia pode ser encontrada no $Q 9$, 63, e também no conceito que se encontra no $Q 6,71$, onde podemos ler: "Até na língua não há partenogênese, isto é, a língua <que> produz outra língua, mas há inovação por interferências de culturas diversas etc.”, se funda na concepção da não-partenogênese das ideias, isto é, na equivalência peculiar posta pela tradutibilidade entre "teoria" e "prática". E, ainda, no $Q 6,71$ onde podese ler: "língua = história" 32 . Mas nós sabemos que, para Gramsci, língua = história, porque língua = política - embora não imediatamente, mas como tentei explicar acima, como resultado de um processo complexo (quando e enquanto acontece). Esta passagem falta no $Q 6,71$, mas Gramsci a tinha já suficientemente clara na cabeça enquanto escrevia este parágrafo, porque é a partir do final de 1930 que ele começa a perceber melhor o caráter "político" não apenas da filosofia, mas também das linguagens racionais em geral. Aliás, ao ler uma citação do $Q$ 6, 10 (novembro-dezembro 1930, o qual, portanto, ou precede ou é contemporâneo do $Q 6,71$ ), vêse que uma virada teórica estava no ar precisamente naquele momento. Ao criticar o jeito olímpico de Benedetto Croce-Erasmo, Gramsci alicerça seu argumento em uma equivalência entre intelectuais-ciência-alta cultura e "vida prática" - "aspectos práticos da cultura", que, aliás, formulará em termos fundamentalmente parecidos no $Q 8,208$ (e no $Q 7,45$ ). E as semelhanças vão além da aparência sintática. De fato, se no $Q 8,208$ ele

\footnotetext{
32 No $Q$ 6, 71, o termo italiano "língua" é utilizado por Gramsci segundo um dos seus significados. Nele, mantém-se uma certa ambiguidade e ambivalência, à medida que indica, ao mesmo tempo, "língua" e "linguagem".
} 
escreverá: "os filósofos explicaram o mundo e se trata agora de mudá-lo, isto é, que a filosofia deve se tornar 'política', 'prática', para continuar a ser filosofia" ( $Q$ 8, 1066 - grifo meu), no $Q$ 6, 10 afirmará: "também o grande intelectual se deve lançar na vida prática, se tornar um organizador dos aspectos práticos da cultura, se quiser continuar a dirigir" $(Q 6,689-$ grifo meu). Isto é, se entende que também no $Q 6,10$ - contemporâneo ou quase do $Q 6,71$ - Gramsci pressupõe a equivalência entre teoria e prática que formulará explicitamente só depois no $Q 8,208$ e que coincide com a tradutibilidade, e a utiliza para interpretar o caráter histórico da língua e da linguagem. Contudo, tudo isto é confirmado, mais uma vez, tanto que na mesma ou em temporada próxima Gramsci continuará desenvolvendo uma série de equivalências que antecipam a teorização no $Q 8,208$ - no $Q$ 7, 33, ali por exemplo, se encontra: Marx = Lênin; no $Q$ 7, 35, 886: filosofia $=$ política - quanto pelo que a ideia do caráter político, ideológico da linguagem - conforme a de Marx na Sagrada família e nas Teses ${ }^{33}$ - está já claramente presente em um texto do $Q 1,44,51$ e em um outro do $Q 1$, 48 , no qual a ideia contida no primeiro se encontra de forma mais sintética. Aqui, se lê que a "linguagem" dos jacobinos, isto é, a sua "ideologia", "era ultra-realista, pois eles fizeram marchar as forças necessárias para conseguirem os fins da revolução e deram à classe revolucionária o poder" $(Q 1,48,61)$.

Desta forma, pode-se concluir que, de um ponto de vista geral, para Gramsci, a afirmação da não partenogênese da linguagem e da língua ( $Q$ 6, 71) é da mesma série à qual pertence a afirmação da não partenogênese da teoria $(Q 9,63)$ e isso implica também o conceito de tradutibilidade. Aliás, o que significa a frase do $Q 6,71,738$ : que as línguas e as linguagens são "expressão cultural de um determinado povo"? Não quer dizer que elas sejam expressão cultural no sentido, ao mesmo tempo, de expressão "política" - conforme o que se encontra no $Q 7,45$ ? Ou seja, de algo que ao mesmo tempo reage sobre o povo transformando seu jeito de pensar, de sentir e de agir ou que constitui um elemento "coletivo-individual" necessário para que o povo possa atuar e "educar" o ambiente?

33 Cf. LACORTE, 2012. 
Que em Gramsci as questões linguísticas sejam questões de políticas, de hegemonia e, contemporaneamente, as questões de hegemonia sejam questões linguísticas; que as lutas para construir uma nova sociedade sejam, ao mesmo tempo, lutas para afirmar novos significados e vice-versa; que a unidade entre teoria e prática, intelectuais e povo, seja o resultado de um processo complexo, no qual a linguagem e a tradução, como elementos culturais-políticos, de consenso e coerção (não se pode esquecer este ponto e falar dos Cadernos como manifestação de um pensamento abstratamente dialógico e pacifico), têm um papel imprescindível, é o que ele desenvolve e esclarece passo a passo. De fato, Gramsci insiste muito sobre o fato de que "[...] linguagem significa também cultura e filosofia (ainda que no grau do senso comum)" e que, então, o "momento cultural" e a posição da "questão da linguagem em geral" são importantes a respeito da "atividade prática (coletiva)", especialmente na moderna sociedade de massa, enquanto a linguagem é, ao mesmo tempo, o "material" histórico-cultural para os seres humanos construir e cimentar determinadas relações sociais (e que pode fragmentá-las), para criar uma vontade e consciência coletiva política; e o "ato histórico" é sempre realizado pelo "homem coletivo", isto é, "pressupõe o alcance de uma unidade "cultural-social' pela qual uma multiplicidade de vontades desagregadas, com fins heterogêneos, se soldam conjuntamente em busca de um mesmo fim, com base numa (igual) e comum concepção do mundo" (Q 10 II, 44, 1330-31). Ele afirma isto depois de ter observado que a nova filosofia deve ser concebida não simplesmente da velha forma "individual", mas, acima de tudo, como "luta cultural para transformar a 'mentalidade' popular e difundir as inovações filosóficas que se demonstrem 'historicamente verdadeiras' ${ }^{34}$ na medida em que se tornem concretamente, isto é, histórica e socialmente, universais" (Q 10 II, 44, 1330 - grifo meu; cf. CC, 1999, v.1, 398) - quer dizer, sejam traduzidas em realidades hegemônicas.

Assim, por exemplo, por causa da Revolução Russa, o significado da palavra "Estado" muda: não é mais o do Estado de Luis XIV, do Estado

\footnotetext{
34 Aqui mudei um pouco a tradução brasileira, por preferir manter o equivalente do verbo italiano "dimostri", com o qual Gramsci, na parte do Caderno 7 dedicada à tradução das Teses sobre Feuerbach, traduz o verbo alemão beweisen, usado por Marx na segunda tese, e cujo significado é "traduzido" através de toda a formulação gramsciana no Q 10 II, 44.
} 
liberal ou, mais em geral, das formas passadas de Estado. Por causa das mudanças produzidas através da política, um novo significado da palavra "Estado", ligado a uma nova consciência e concepção do mundo, deve ser acrescentado ao dicionário, o que demonstra, ao mesmo tempo, a eficácia política da própria nova linguagem-concepção à qual a palavra Estado pertence. Contudo, como se vê, pode mudar o significado, mas não (ou não imediatamente) o significante, a forma exterior de uma linguagem, pois

nenhuma nova situação histórica, mesmo a derivada da mudança mais radical, transforma completamente a linguagem, pelo menos em seu aspecto exterior, formal. Mas o conteúdo da linguagem deveria ter mudado, ainda que seja difícil, de imediato, ter consciência exata desta modificação (Q 11, 16, 1407; CC, 1999, p. 124).

Além disso, Gramsci sabe que "uma nova classe que se torna dirigente inova [a língua - R. L.] em 'massa", mas também que as mudanças linguísticas nem sempre ocorrem em ligação direta e imediata com as transformações radicais de uma sociedade, pois elas ocorrem também de forma "molecular": "O latim inovou o céltico da Gallias em 'massa' e, ao contrário, influenciou o germânico 'molecularmente', isto é, emprestando-lhe palavras ou formas singulares, etc." $(Q 6,71,739)$ e a realização de uma nova hegemonia não é algo que acontece simplesmente de forma repentina, mas algo que é precedido de milhões de mudanças moleculares que podem intervir entre nações diferentes ou dentro da mesma nação, camadas sócias dela, etc. (cfr. $Q 6,71,739$ ).

\section{A tradutibilidade: coração da filosofia da práxis}

O que tratamos acima deveria ajudar a entender melhor porque a tradutibilidade é o núcleo teórico central da filosofia da práxis. Gramsci concebe a práxis como conjunto prático-teórico em movimento, mas a tradutibilidade é a teoria deste conjunto, à medida que é a "teoria da unidade de teoria e de prática" $(Q 8,208,1066)$. Portanto, a tradutibilidade é o que Gramsci utiliza para pensar a (e desenvolver o conceito de) práxis, por isso, constitui o coração teórico desta nova filosofia. Com efeito, em relação ao primeiro aspecto, o autor dos Cadernos, ao estabelecer em que 
termos se possa falar de "Materialismo histórico" $(Q 4,37)$ ou, mais tarde, de "filosofia da práxis" (texto C no $Q 11,69$ ), como uma nova forma de "monismo" (do grego antigo "mónos" que significa "um", a ser referido a essa unidade de elementos heterogêneos da qual falávamos acima), afirma que este último se funda no novo conceito de práxis, entendida como “atividade do homem (história) em concreto" ( $Q$ 4, 37, 455, setembrooutubro de 1930). Ao reescrever este texto posteriormente, ele acrescenta - e este acréscimo é crucial para entender melhor o próprio conceito de práxis - que este novo "monismo" é uma filosofia do "ato impuro", pois pensa nele como "identidade dos contrários no ato histórico concreto" $(Q$ 11, 69, 1492, agosto-fim de 1932 ou início de 1933). Quer dizer, "matéria" e "espírito", "prática" e "teoria", intelectuais e povo, etc., embora diferentes, não são elementos contraditórios. De fato, a tradução entre eles demonstra que estão em oposição de contrariedade. Portanto, a filosofia da práxis pensa na própria identidade de maneira diferente da TDO, isto é, como uma dinâmica político-histórica na qual realmente se unificam e podem se unificar atividades contrárias ou diferentes.

Mas "buscar a real identidade na aparente diferenciação e contradição e encontrar a substancial diversidade sub a aparente identidade" (Q 1, 43, 33-34, dezembro 1929-fevereiro 1930) é o próprio critério, tarefa e atividade do tradutor entendido em sentido estrito e, ao mesmo tempo, amplo e forte. De fato, o autor dos Cadernos explicará que quem "sabe traduzir um mundo cultural na linguagem de um outro mundo cultural" é quem "sabe encontrar as semelhanças também onde parece que não existam e sabe encontrar as diferenças também onde parece que tenham apenas semelhanças, etc." ( $Q 7,81,914$, dezembro 1931). Portanto, o critério ilustrado no $Q 1,43$ e a tradução como a interpreta Gramsci coincidem - já que a própria atividade do tradutor, no sentido estrito, não deve ser entendida como atividade meramente linguística, mas em um sentido mais amplo, na medida em que é sempre parte de um processo mais vasto (guerra de posição, estruturas ideológicas, luta cultural como luta "prática"), o qual implica, ao mesmo tempo, o papel político dele. A tradução, como a concebe Gramsci, e o critério ilustrado no Q 7, 81 citado acima coincidem, desde que não se transforme este mesmo critério em algo para buscar abstratamente qualquer tipo de analogia entre fenômenos diferentes ou de diferenças 
entre fenômenos aparentemente idênticos ${ }^{35}$. Com efeito, a análise deve sempre partir do estudo dos efeitos concretos, políticos, de determinadas atividades, que produzam ou contribuam com a produção de elementos historicamente permanentes ou tendencialmente, comparando-os para ver se entre eles existem reais diferenças ou analogias. Por isso, para analisar os fenômenos culturais, sociais, políticos e históricos e para criar novos conceitos e critérios prático-teóricos "realistas", é necessário partir daqui.

Assim, através da tradutibilidade, Gramsci coloca-se também na condição de analisar os tipos de relações que existem entre determinadas atividades humanas: se estão em relação dialética e de qual tipo (diferença, contrariedade, contradição). No caso da relação de tradução recíproca a dialética nunca será entre atividades contraditórias, porque contraditórias são só as atividades que produzem efeitos contraditórios e, por isso, não podem ser traduzidas reciprocamente (embora exista uma certa margem de tradução, pelo menos em relação aos "valores instrumentais" de cada atividade-linguagem). Por exemplo, a práxis dos nobres é uma expressão da civilização feudal e da dos burgueses antes e durante a Revolução francesa; a filosofia da práxis traduz os valores instrumentais do idealismo (cf. $Q 10$ II, 6, ii), mas está em contradição com ele pois expressa (ou tenta expressar) uma práxis antagônica à da burguesia. E o pensamento idealista expressou a especificidade cultural burguesa alemã. Portanto, o que Gramsci escreve no $Q 8,208$ e nos outros textos analisados anteriormente é a teorização do critério para entender a práxis e para distinguir entre contradições $e$ diferenças reais e aparentes, entre dialética real e aparente. Isto ajuda a

\footnotetext{
${ }^{35}$ Gramsci observa que, em geral, os "intelectuais profissionais" "adquiriram o hábito e a disciplina mental necessários para conectar rapidamente conceitos aparentemente diferentes", e vice-versa (Q 16, 29). Este conceito (a tradutibilidade), relativamente ao período carcerário, se encontra (implícito) já no plano de trabalho exposto na carta para Tania de 19 de março de 1927. Nela, Gramsci indica uma série de quatro temas que quer aprofundar e na conclusão acrescenta que, apesar da aparente diferença, "para quem olha bem, existe homogeneidade entre estes quatros argumentos [...]". Contudo, há vários intelectuais que não (ou não sempre) conseguem fazer isso do jeito correto, isto é, que não conseguem "traduzir" e, portanto, suas análises e afirmações resultam abstratas, desligadas da realidade. Entre eles, Gramsci lista: Sorel e De Man (Q 4, 31), Croce (Q 4, 3; Q 6, 10, etc.), Bucharin (Q 11, 26), Loria (Q 1, 25), Ferrari (Q 1, 44, 44), etc. Quando o critério mencionado acima não é usado da forma correta, realista, não coincide com a tradutibilidade no sentido gramsciano. Trata-se de um critério usado pelos gregos antigos e estudado e usado na Itália (barroca), por Emanuele Tesauro e Giambattista Vico.
} 
entender o que o autor dos Cadernos escreve cerca de um ano e meio antes deste parágrafo. Nele, refere-se ao que historicamente aconteceu na França e na Alemanha nos séculos XVIII e XIX, onde diferentes "linguagens" (o político francês e o filosófico alemão) se tornam realidade, ou seja, produzem efeitos reais. Ao comparar os efeitos dos dois, descobre-se que, apesar de cada atividade ser diferente da outra, os seus efeitos são fundamentalmente parecidos porque produzem a mesma realidade (a realização da hegemonia da burguesia francesa através de uma revolução ativa na França, com a participação ativa do povo, e da hegemonia da burguesia alemã através de uma "revolução passiva", conduzida pelo alto por intelectuais burgueses alemães) e portanto são traduziveis reciprocamente ( $Q 4,42,467-68$, outubro 1930). Então, ao analisar os seus efeitos reais, descobre-se que estas práxis diferentes não resultam contraditórias, mas se as analisamos do ponto de vista das transformações que elas produziram, em nível mais profundo, descobrimos que remetem à mesma práxis e visão do mundo. $\mathrm{E}$, de fato, já antes, com referência implícita à tradutibilidade $(Q 1,44,51)$ e à construção histórico-políticocultural da hegemonia burguesa, na Europa dos séculos XVIII-XIX, Gramsci afirma que houve um "diferente manifestar-se do mesmo fenômeno em países diferentes" ( $Q$ 1, 44, 54 - grifo meu). Em outras palavras, o próprio Gramsci afirma que, neste caso, estas diferentes "linguagens" ou práxis equivalem a expressões diferentes da mesma práxis em movimento.

\section{Os conceitos de "práxis", "imanência" e "filosofia da práxis" à luz da ideia de tradutibilidade ${ }^{36}$}

Este olhar para os fenômenos históricos é o desenvolvimento do novo olhar de Marx. Dentro dele, Gramsci encontra uma nova filosofia, autônoma e original, que deve ser ulteriormente desenvolvida (cf., por ex., $Q 4,3$ e $Q$ 7, 33). No $Q 4,46$ (outubro-novembro 1930), o revolucionário sardo já afirmara, ao referir-se à relação entre "Filosofia-PolíticaEconomia" (como titula este parágrafo), que "se se trata de elementos

\footnotetext{
36 Esta parte deste ensaio, aqui reelaborada, foi apresentada no Seminário Internacional “Gramsci e os Movimentos Populares", 13-16 de setembro de 2010, organizado pelo NuFiPE, UFF, <http://www.nufipeuff.org/seminario_gramsci.html $>$.
} 
constitutivos de uma mesma concepção do mundo"37, os "princípios teóricos" de cada um se podem reciprocamente traduzir "na própria específica linguagem de cada parte constitutiva". Neste caso, segundo Gramsci, "um elemento é implícito no outro e todos juntos formam um círculo homogêneo" ( $Q 4,472$ - grifos meus). Quando Gramsci reescreveu este texto, destacou o aspecto ativo destes elementos e acrescentou que estes são "três atividades" ( $Q$ 11, 65, 1492, entre agosto e o fim de 1932 ou o início de 1933: CC, 1999, v. 1, p. 209 - grifo meu), precisamente no sentido de práxis transformadora do mundo. Com efeito, este acréscimo não constitui só uma mudança terminológica, pois enquanto escrevia estes dois textos, Gramsci, como já vimos, estava ulteriormente elaborando a tradutibilidade, no $Q 10$ II, 9 (segunda metade de maio de 1932) e na carta para Tania (30 maio 1932), buscando chegar a uma formulação mais geral, para mostrar que a tradução não acontece apenas entre linguagens, no sentido estrito, mas entre atividades humanas.

Retornando ao assunto no $Q 10 \mathrm{II}$, 9, o teórico sardo usará o critério da tradutibilidade para explicar como nasceu a filosofia da práxis e afirmará que viu a luz através do seu uso (implícito) por Marx, isto é, de uma "tradução". De fato, ele afirma que "a filosofia da práxis elaborou sinteticamente os três movimentos" (filosofia, política e economia), "isto é, toda cultura da época, e que na nova síntese, em qualquer momento que se examine, momento teórico, econômico, político, reencontra-se como 'momento' preparatório cada um dos três movimentos". Quer dizer, a expressão "prática" de uma práxis deixa implícito seu lado teórico, assim como a sua expressão "teórica" deixa implícito seu lado prático, mas isso não quer dizer que cada expressão ou atividade humana (práxis) não seja, ao mesmo tempo, um conjunto inscindível de ambos, embora

37 Cabe notar que aqui, para Gramsci, a noção de concepção do mundo implica que ela não seja considerada simplesmente como atividade teorética: no $Q 10 \mathrm{II}, 5,1217-18$ ele escreve que "é religião toda filosofia, ou seja, toda concepção do mundo, à medida em que se tornou 'fé', isto é, em que é vista não como atividade teorética (de criação de um novo pensamento), mas sim como estimulo à ação (atividade ético-política concreta, de criação de nova história)" (CC, 1999, v. 1, p. 289 - grifo meu). E, de fato, no Q 4, 46 ele está falando de elementos teóricos que podem se tornar práticos e vice-versa, se pertencerem à mesma concepção do mundo, isto é, entendida como algo que já subverteu a práxis afirmando a nova, ou que tende a subvertê-la, enquanto tem já alcançado o "momento" "ético-político". 
um lado seja mais (ou menos) histórica e culturalmente desenvolvido do que o outro. Este é o resultado da "tradução" como a fez e a entendeu Marx. Através dela se demonstra que o caráter comum às três atividades é a indissociabilidade, em cada uma, de prática e teoria, ou seja, a imanência recíproca destes aspectos (que acontece só no "ato concreto" e por isso não é "imanência especulativa"), que é o novo conceito que as sintetiza e dele se deduz o caráter terreno de qualquer atividade humana racional ou práxis: "O momento sintético unitário deve ser identificado no novo conceito de imanência, que da sua forma especulativa, tal como era apresentada pela filosofia clássica alemã, foi traduzido em forma historicista graça a ajuda da política francesa e da economia clássica inglesa" (Q 10 II, 9, 1246-47).

Com grande escândalo dos idealistas como Croce (1922), ficou claro que a filosofia poderia se encontrar "implícita" na política e até na economia. E, no $Q 7,1$, como vimos, Gramsci já afirmara que a "estrutura" não é "algo imóvel", mas "realidade em movimento", pois acontece que a "superestrutura" é algo que "reage dialeticamente sobre a estrutura e a muda" (idem, 854). Pouco depois teria confirmado que a "práxis" não é e não deve ser entendida como algo que se opõe à "teoria", ou seja prática esvaziada de pensamento, mas é uma relação entre a "vontade humana (superestrutura) e a estrutura econômica" ( $Q 7,18$, novembro-dezembro 1930 - fevereiro 1931). Contudo, é ao desenvolver progressivamente o conceito de tradutibilidade que Gramsci procura entender melhor esta relação dinâmica, ou seja, a práxis, como demonstra o retrato ainda mais complexo dela que ele desdobra sucessivamente.

Portanto, o próprio conceito de tradutibilidade ilumina o de práxis e o de práxis, junto com o primeiro, o de imanência, isto é, o relativo ao caráter terreno de qualquer atividade humana. Na carta para Tania e no $Q 10$ II, 9, Gramsci investiga com novos olhos na estrutura da própria "prática" (cabe notar que até a primavera de 1932 ele não mencionara Ricardo e o papel da sua teoria econômica a respeito do nascimento da filosofia da práxis). Para ele, Marx entendeu que na economia e na teoria econômica de David Ricardo há elementos (as "leis tendenciais", etc.) que têm um alcance "gnosiológico" e, por isso, podiam se desenvolver em uma nova concepção de mundo. Gramsci escreve: "Ricardo tivera um significado na história da filosofia além do significado na história da ciência econômica" 
$(L C, 581)$, e acrescenta:

A descoberta do princípio lógico formal da "lei tendencial", que leva a definir cientificamente os conceitos fundamentais na economia de "homo economicus" e de "mercado determinado" não foi uma descoberta de valor também gnosiológico? Não implica mesmo uma nova "imanência", uma nova concepção da "necessidade" e da liberdade, etc.? (LC, 581).

Tratava-se, portanto, de ver "como e em que medida", além da política francesa e da filosofia alemã, "ao ulterior desenvolvimento da nova teoria tenha contribuído a economia clássica inglesa, na forma metodológica elaborada por Ricardo" (LC 582).

Nas "leis tendenciais" ricardianas e no conceito de "mercado determinado" derivado delas encontra-se, creio, um paradigma práticoteórico que exemplifica a tradutibilidade, ou seja, o nexo entre "atividades cientificas e atividades práticas" ( $L C, 582)$, de uma forma ainda mais clara do que o da política francesa em relação ao da filosofia alemã $\tilde{a}^{38}$. A respeito disso, na carta para Tania, Gramsci conjectura que, por um lado, ao partir "destes dois conceitos" ("mercado determinado" e "lei tendencial"), Marx teria operado "a redução ['tradução' - R. L.] ${ }^{39}$ da concepção 'imanentista'

38 Na carta para Tania, Gramsci faz a seguinte observação: "Que a economia clássica inglesa tenha contribuído ao desenvolvimento da nova filosofia é comumente admitido, mas se pensa usualmente à teoria ricardiana do valor". Gramsci, ao contrário, pensa nas leis tendenciais e de mercado determinado. E acrescenta que lhe "parece que deva-se olhar mais além" (LC 582). Com efeito, poucas linhas antes, ele formulara a hipótese que "Ricardo tivera um significado na história da filosofia além da história da ciência econômica" $(L C$, 581). Portanto, "além" indica que Gramsci está enfrentando Ricardo e a sua metodologia por meio da tradutibilidade: o olhar sobre a obra dele deve ser "não apenas analítico, referido a uma doutrina particular". Quer dizer, nesta obra não se deve só (= analiticamente) reconhecer o que se limita à esfera da economia, mas também "identificar uma contribuição que diria sintética" - prossegue Gramsci - "isto é, que concerne a intuição do mundo e o jeito de pensar" ( $L C, 582-83)$. E a tradutibilidade expressa, contemporaneamente, a necessidade e a própria capacidade de ir além do olhar analítico e unilateral, e de individuar nexos substanciais, permitindo assim sintetizar em novos conceitos os elementos que se encontram conectados, apesar das suas aparentes diferenças.

39 Gramsci usa, usualmente, o termo "redução" para indicar um tipo de tradução, a não "recíproca", na qual nem tudo dos elementos a serem traduzidos pode ser traduzido, mas sim, pelo menos, "o valor instrumental". 
da história - expressa com a linguagem idealista e especulativa por Hegel para uma 'imanência' realista imediatamente histórica" (expressa em uma linguagem realista por Marx). Por outro lado, ele assevera que "a lei de causalidade das ciências naturais foi depurada do seu mecanicismo e foi sinteticamente identificada com o raciocínio dialético do hegelianismo" (LC 582). Também no texto dos Cadernos, Gramsci apontara uma ideia análoga: "Em um certo sentido me parece que se possa dizer que a filosofia da práxis é igual a Hegel + David e Ricardo" (Q 10 II, 9, 1247). Em outras palavras, por um lado, Marx teria descoberto que entre a linguagem de Hegel e a de Ricardo pode estabelecer-se uma equivalência, na qual não só o primeiro esclarece o que acontece no segundo, mas também o segundo ilumina o que acontece no primeiro. Isto é, a linguagem filosófica tem (quando enquanto os tem) efeitos transformadores da realidade, apesar de parecer muito abstrata - e parece iluminar isto melhor do que a linguagem da política francesa pois, no paradigma ricardiano, e em particular no conceito de "mercado determinado", vem à tona, de forma mais clara, a "imanência" a uma determinada configuração histórico-social de qualquer linguagem teórica. Com efeito, o mercado determinado consiste em uma "“determinada correlação de forças sociais em uma determinada estrutura do aparelho de produção' [...] garantida (isto é, tornada permanente) por uma determinada superestrutura política, moral, jurídica" ( $Q 11$, 52,1477 ), isto é, por determinadas linguagens e elementos culturais, os quais produzem "paixões" e "sentimentos imperiosos" que induzem "à ação 'a todo custo" "40 e que, por isso, "garantem", ou seja "determinam"

40 'Parece que o conceito de 'necessidade' histórica está estreitamente ligado ao de 'regularidade' e de 'racionalidade'. A 'necessidade' no sentido 'especulativo-abstrato' e no sentido 'histórico-concreto'. Existe necessidade quando existe uma premissa eficiente e ativa, a consciência da qual nos homens se tornou operante, ao colocar fins concretos à consciência coletiva e ao constituir um complexo de convicções e de crenças que atua poderosamente como as 'crenças populares'. Na premissa devem ser contidas, já desenvolvidas ou em via de desenvolvimento, as condições materiais necessárias e suficientes para a realização do impulso de vontade coletiva; mas é evidente que desta premissa 'material', quantitativamente calculável, não pode ser destacado um certo nível de cultura, isto é, um conjunto de atos intelectuais e destes (como seu produto e consequência) um certo complexo de paixões e de sentimentos imperiosos, isto é, que tenham a força de induzir à ação 'a todo custo'”' (Q 11, 52, 1479-80; cf. CC, 1999, v. 1, 196-97 - o segundo grifo é meu). 
a "estrutura", mas, se faltarem, faltará também todo o "mercado". Para Gramsci, o fato do modelo ricardiano não ser determinista é de importância crucial, pois na sua ideia de mercado determinado as superestruturas são o elemento necessário, já que também determina a estrutura modificando-a, diferentemente do modelo materialista mecânico da sociedade ou da interpretação do modelo ricardiano segundo o determinista e mecânico dos economistas neoclássicos:

O automatismo é em contraste com o arbítrio, não com a liberdade. [...] É uma liberdade de grupo, em oposição ao arbítrio individualista. Quando Ricardo dizia: "postas estas condições", haverá tais consequências em economia, não tornava "determinista" a própria economia, nem sua concepção era "naturalista". Observava que, posta a atividade solidária e coordenada de um grupo social, que opera segundo determinados princípios aceitos por convicção (livremente) em vista de determinados fins, tem-se um desenvolvimento que se pode chamar de automático e que pode ser assumido como desenvolvimento de certas leis reconhecíveis e isoláveis com o método das ciências exatas (Q 10 II, 8, 1246; cf. CC, 1999, v. 1, p. 316).

Desta forma, pode-se compreender porque Gramsci fala, por um lado, de uma "redução" de Hegel a Ricardo. De fato, através do "raciocínio dialético do hegelianismo", a nova filosofia "tem universalizado as descobertas de Ricardo estendendo-as adequadamente para toda a história, e extraindo delas, portanto, uma nova concepção do mundo" ( $Q 10 \mathrm{II}$, 9, 1247; CC, 1999, v. 1, p. 318). Em relação a esta questão, Gramsci já observara que "para a filosofia da práxis o próprio método especulativo não é futilidade, mas foi fecundo de valores 'instrumentais' do pensamento, que a filosofia da práxis incorporou (a dialética, p. ex.)" (Q 10 I, 1211; CC, 1999, vol. 1, p. 283; cfr. $Q$ 10, 1235). Quer dizer, por um lado, Marx teria interpretado como "momento" (dialético) de um devir histórico mais amplo o que o modelo ricardiano descreve abstratamente - embora Gramsci destaque que esta abstração de Ricardo seja uma "abstração determinada". Ele teria traduzido o "valor instrumental" da dialética - como para Gramsci se pode deduzir ao ler as Teses marxianas, em particular a segunda e a 
terceira (sobre a recíproca influência de homem e ambiente, "estrutura" e "superestrutura", etc.). Por outro lado, a teria utilizado para interpretar as dinâmicas dialéticas internas ao próprio modelo ricardiano do mercado determinado, que são as mesmas que o conectam para toda história através de seu próprio desenvolvimento político e histórico. Isto parece implicar o conceito da extensão "para toda a história" das "descobertas de Ricardo" e, portanto, também da lei tendencial.

Com efeito, cabe observar que, para Gramsci, as leis econômicas de tendência não são "naturais" ou "do determinismo especulativo", mas são "superestruturas" históricas que explicam o mercado determinado e que podem ser compreendidas só enquanto este mercado "acontece". Contudo, ele "acontece" porque é sempre um conjunto prático-teórico não naturalmente, mas historicamente, necessário, isto é, cuja "necessidade", ou melhor regularidade ${ }^{41}$, é o resultado, como acenamos acima, da dialética interna entre "prática" e "teoria", economia e cultura. E as "leis" se referem, no caso ricardiano, a este conjunto dinâmico teoria-prática, superestruturaestrutura, enquanto estes elementos estiverem em uma configuração relativamente (isto é, politicamente e historicamente) equilibrada e estável. Por isso, são tendenciais, ou seja, históricas e não eternas.

Gramsci acrescenta também que "a economia estuda estas leis tendenciais enquanto expressões quantitativas dos fenômenos"; os históricos e políticos (como Gramsci) também enquanto expressões "qualitativas", isto é, enquanto são, ao mesmo tempo, linguagensideologias e "história", a ser conhecidas não só para conservar mas também para "subverter a práxis". A extensão do modelo ricardiano para toda a história é uma tradução entre paradigmas científicos (o das ciências naturais e o histórico-dialético) que tem duas implicações entrelaçadas: a passagem deste modelo do âmbito da causalidade das ciências naturais para o histórico e social, no qual também a vontade do ser humano determina o ambiente - isto é, é "causa" que produz seus efeitos tanto quanto o "ambiente" - e a consideração da dialética interna ao próprio modelo -

41 O de "regularidade" é o novo conceito por meio do qual Gramsci, a partir do fim de 1931, expressa a ideia de "necessidade" no campo histórico. Cf. $Q$ 8, 186, dezembro 1931 e $Q 8,128$, abril 1932 . 
entre "estrutura" e "superestruturas" (linguagens-pensamento expressões de uma determinada vontade coletiva), "quantidade" e "qualidade", "necessidade" e "liberdade", etc. - que é a que gera o próprio movimento histórico. De fato, a tradutibilidade explica que qualquer teoria "racional" e, então, lei econômica elaborada pelos seres humanos não transcende a ideologia (ou seja é "imanente") e neste sentido deve ser considerada como tendencial, isto é, expressão do devir histórico ${ }^{42}$. Que exista uma lei significa, por um lado, que foi constituído um "automatismo" (uma certa sociedade). Ele é o que permite elaborar teorias e leis que o descrevem e o expressam; por outro lado, porém, estas leis têm limites históricos, pois sempre existem "forças contra-operantes" (Q $10 \mathrm{II}, 36,1282$; CC, 1999, vol. 1, p. 352) que, de alguma maneira, ao trabalhar para mudar a "base do "automatismo"" (Q 10 II, 8, 1246), põem ou tentam pôr em crise a "legalidade", o "mercado determinado" já existente, para construir o novo, isto é, a nova sociedade.

Isto não significa que o papel da "política francesa" perca a sua importância - de fato, perto do fim de $Q 10$ II, 9, 1248, Gramsci repete que devemos "relacionar Ricardo com Hegel e com Robespierre". Mas, por um lado, a consideração do papel da linguagem da economia inglesa ajuda a explicar a quebra radical de Marx com a imanência especulativa de Hegel e com toda a filosofia tradicional; por outro lado, explica que Marx, ao se ajudar com a linguagem da dialética hegeliana, chegará a dar uma interpretação dialética das próprias descobertas de Ricardo, superando a leitura "naturalista" dos fenômenos econômicos, depurando-os "do seu mecanicismo" e formulando também a ideia revolucionária de "abstração determinada" ${ }^{\prime 4}$. Portanto, o sentido da referência de Gramsci a Ricardo no

42 “A significação de 'tendencial', ao que parece, deveria ser portanto de caráter 'histórico' real e não metodológica: o termo serve, precisamente, para indicar este processo dialético cujo impulso molecular progressivo conduz a um resultado tendencialmente catastrófico no conjunto social, resultado de onde partem outros impulsos singulares progressivos num processo de contínua superação, o qual, contudo, não se pode prever como infinito, ainda que se desagregue em um número muito grande de fases intermediárias de diversa medida e importância" (Q 10 II, 36, 1283; CC, 1999, v. 1, p. 352 s.).

43 De acordo com Gramsci, Ricardo deu à luz a um "princípio lógico formal da "lei tendencial"" ( $Q 10 \mathrm{II}, 9)$, no sentido que forneceu "um esquema abstrato de uma determinada sociedade econômica", isto é, por um lado, um "esquema abstrato" e, por 
Q $10 \mathrm{II}, 9$, parece ser porque, de um certo ponto de vista, Marx assumiu as implicações teóricas e históricas da sua concepção (em relação à dialética hegeliana) - mais do que as da política dos franceses (mecanicistas e deterministas em filosofia) - que ele teria finalmente conseguido traduzir o imanentismo especulativo de Hegel para a nova imanência realista, tirando da própria dialética hegeliana o seu caráter de "romance filosófico" e, ao mesmo tempo, do conceito de "determinação" o seu caráter mecanicista (ligado, direta ou indiretamente, ao materialismo francês), e dando à luz a sua nova e original concepção do mundo, a filosofia da práxis. E o significado desta última expressão, à luz do que analisamos parece ser, em síntese: atividade humana teórica que se pensa como e é, ao mesmo tempo, atividade humana transformadora, revolucionária, isto é, práxis. Isso é o que Gramsci expressa com energia ao afirmar que "a filosofia da práxis é uma expressão das contradições históricas - aliás, é sua expressão mais completa porque consciente" $(Q 11,62,1488$, testo $C$ di $Q 4,45$; grifo meu).

\section{Referências}

BOOTHMAN, D. Traducibilità e processi traduttivi. Un caso: A. Gramsci linguista. Perugia: Guerra Edizioni, 2004.

CROCE, B. Estetica come scienza dell'espressione e linguistica generale. Bari: Laterza, 1922.

FROSINI, F. La religione dell'uomo moderno. Roma: Carocci, 2010. . Gramsci e la filosofia. Roma: Carocci, 2003.

GRAMSCI, A. Quaderni del carcere. Org. V. Gerratana. Torino: Einaudi, 1975.

outro, "de uma determinada sociedade econômica". Por isso, não se tratava de uma abstração desamarrada do real, mas de uma "abstração determinada". Só sucessivamente esta abstração foi transformada (acima de tudo pelos economistas neoclássicos) em uma linguagem econômica abstrata: "[...] a esta construção científica realista e concreta [de Ricardo - R.L.] foi-se sobrepondo uma nova abstração mais generalizada do 'homem' como tal, 'a-histórico', genérico, abstração que pareceu a 'verdadeira' ciência econômica" $(Q 11,52,1477-78)$. 
Einaudi, 1965.

. Lettere dal carcere. Org. S. Caprioglio; E. Fubini. Torino:

. Cadernos do cárcere, Volume 1. Edição e Tradução C. N. Coutinho (co-edição); L. S. Henriques; M. A. Nogueira. Rio de Janeiro: Civilização Brasileira, 1999.

- Cadernos do cárcere, Volume 2. Edição e Tradução C. N. Coutinho (co-edição); L. S. Henriques; M. A. Nogueira. 3 ed. Rio de Janeiro: Civilização Brasileira, 2004.

- Cadernos do cárcere, Volume 3. Edição e Tradução C. N. Coutinho (co-edição); L. S. Henriques; M. A. Nogueira. 2 ed. Rio de Janeiro: Civilização Brasileira, 2002.

IVES, P. Gramsci's politics of language: engaging the bakhtin circle and the frankfurt school. Toronto: University of Toronto Press, 2004.

. Language and hegemony in Gramsci. London and Ann Arbor (MI): Pluto Press, 2004.

KANOUSSI, D. Introducción a "los Cuadernos de la cárcel” de Antonio Gramsci. Mexico: Plaza y Valdés, 2000.

LACORTE, R. Sulla presenza dei concetti di "traducibilità", "lingua" e "rivoluzione passiva" di Antonio Gramsci in Petrolio di Pier Paolo Pasolini. In: MAGGI, A.; WEST, R. (Org.). Scrittori inconvenienti. Ravenna: Longo Editore, 2009.

. Translatability, language and freedom in Gramsci's prison notebooks. In: IVES, P.; LACORTE, R. (Org.). In: Gramsci, language, and translation. Lanham: Lexington Books, 2010.

. Espressione e traducibilità nei quaderni del carcere. In: DURANTE, L.; LIGUORI, G. (Org.). Domande dal presente: studi su Grasmci. Roma: Carocci, 2012.

. et al. Sobre a "tradutibilidade" de Gramsci e algumas transformações sociais na Itália e no Brasil. In: D’ANGELO, M.; SEMERARO, G. (Org.). Encontros com a filosofia (En-fil.net). Niterói. Dezembro 2013.

LIGUORI, G.; VOZA, P. (Org.). Dizionario gramsciano 1926-1937. Roma: Carocci, 2009. 
LO PIPARO, F. Lingua intellettuali egemonia in Gramsci. Roma-Bari: Laterza, 1979.

Gramsci and Wittgenstein. An intriguing connection. In: CAPONE, A. (Org.). Perspectives on language use and pragmatics. Mnchen: Lincom, 2010, p. 285-320.

LOSURDO, D. Gramsci, Gentile, Marx e le filosofie della prassi. In: MUSCATELLO, B. (Org.). Gramsci e il marxismo contemporâneo. Roma: Editori Riuniti, 1990.

SANGUINETI, F. Gramsci e Machiavelli. Bari: Laterza, 1981.

SCHIRRU, G. Egemonia e prestigio linguistico. In: Egemonia: usi e abusi di uma parola controversa. Atti del Convegno tenutosi a Napoli - Salerno: 27-28 ottobre 2005.

SEMERARO, G. Gramsci e os novos embates da filosofia da práxis. Aparecida: Ideias e Letras, 2006.

Data de registro: $06 / 03 / 2014$ Data de aceite:23/04/2014 